NOTE

\title{
Terrestrial trophic subsidy in sandy beaches: evidence from stable isotope analysis in organic matter sources and isopod Excirolana armata
}

\author{
Leandro Bergamino*, Diego Lercari, Omar Defeo \\ Unidad de Ciencias del Mar, Facultad de Ciencias, Iguá 4225, Montevideo 11400, Uruguay
}

\begin{abstract}
We examined the assimilation of terrestrial organic matter (TOM) by the ovoviviparous isopod Excirolana armata inhabiting an exposed sandy beach of Uruguay. The source of this terrestrial input was an artificial freshwater discharge (the Andreoni Canal). We analyzed carbon $\left(\delta^{13} \mathrm{C}\right)$ and nitrogen $\left(\delta^{15} \mathrm{~N}\right)$ isotope ratios in the TOM, in seawater particulate organic matter (POM) and in E. armata at 3 beach sites: Andreoni, at the canal mouth, Coronilla, at $1 \mathrm{~km}$ from the mouth and Barra, at $13 \mathrm{~km}$ from the mouth. Our analysis revealed clear effects of the canal discharge on the beach ecosystem. TOM was observed in the beach-face detrital mixture only at Andreoni; it also showed the lowest isotopic values there. POM $\delta^{13} \mathrm{C}$ values were also lowest near the canal mouth (increasing with distance from the mouth), indicating the dominance of terrestrial material in the carbon pools of sites closest to the freshwater discharge (viz. Andreoni and Coronilla). The same trend was seen in E. armata. Mixing-model (IsoSource) results for E. armata at Andreoni and Coronilla suggested that TOM was the main contributor to diet at these sites, while POM was the main contributor at Barra. We concluded that E. armata is a useful indicator of TOM assimilation in sandy-beach ecosystems. Our results point up the need, when studying sandy beach food webs, to consider potential modifications by terrestrial allochthonous inputs.
\end{abstract}

KEY WORDS: Trophic subsidy - Excirolana armata - Freshwater discharge · Sandy beaches . Stable isotopes · Uruguay

Resale or republication not permitted without written consent of the publisher

\section{INTRODUCTION}

Sandy beaches provide a wide range of ecosystem services, including harvestable resources, production and processing of organic matter, flood protection, nursery areas for juvenile fishes and human recreation (Defeo et al. 2009). These ecosystems, however, are being widely affected by human activities (McLachlan \& Brown 2006). Particularly, organic inputs from freshwater discharges have become important stressors in these environments, potentially affecting nutrient regimes and ecological communities and also modifying the environment (Dagg et al. 2004, Schlacher et al. 2007 and references therein).
Trophic subsidy is widely recognized as a key factor in structuring communities, affecting the distribution and interactions of prey and predators (Polis et al. 1997, Nakano \& Murakami 2001). On sandy beaches, food webs are based mainly on marine sources, such as phytoplankton, wrack (stranded algae and seagrasses) and carrion (McLachlan \& Brown 2006), with the influence of these marine subsidies decreasing at increasing distances inland (Colombini et al. 2011). However, little is known about the consequences to these ecosystems of terrestrial-resource subsidies (but see Schlacher \& Connolly 2009, Colombini et al. 2011). The links between terrigenous matter and the marine intertidal system are much closer than previously estimated 
(Schlacher \& Connolly 2009). Moreover, recent research has demonstrated that impacts of river inputs on marine coastal ecosystem dynamics include increases in terrestrial particulate organic matter (POM), which is directly consumed by depositfeeding invertebrates, and which also affects fish abundance (Darnaude et al. 2004, Sampaio et al. 2010). It has therefore become increasingly critical to understand how trophic subsidies affect beach ecosystems, in order to properly assess functional relationships between sandy beach macrofauna and the nature and extent of ecosystem productivity.

Stable isotopes of carbon $\left(\delta^{13} \mathrm{C}\right)$ and nitrogen $\left(\delta^{15} \mathrm{~N}\right)$ are useful tools for tracing the long-term assimilation of different energy sources by resident fauna (Fry 2006). On average, $\delta^{13} \mathrm{C}$ values of consumers are expected to increase by $\sim 1 \%$ over the values of their food sources, and $\delta^{13} \mathrm{C}$ can therefore be used to identify the carbon sources in food webs (Peterson \& Fry 1987). On the other hand, $\delta^{15} \mathrm{~N}$ increases by $\sim 3.4 \%$ in consumers relative to their standard food sources, providing an estimate of their trophic position (Peterson \& Fry 1987). Despite the wide use of stable isotope analysis to identify indicators of human impact on several terrestrial and marine ecosystems (Vizzini \& Mazzola 2006, Sampaio et al. 2010), this technique has been rarely applied in sandy beach environments. This is of the utmost importance, because these ecosystems comprise $\sim 70 \%$ of open-ocean coasts and their position at the land-sea margin renders them highly vulnerable to human activities developed in, or close to, the coastal zone (Defeo et al. 2009).

Our area of interest was $22 \mathrm{~km}$ of sandy beach in the department of Rocha, eastern Uruguay, a beach affected by a freshwater discharge from the Andreoni Canal, which drains an area used for agriculture and cattle-rearing. Previous work documented the impact of this freshwater discharge on resident sandy-beach populations of intertidal clams Mesodesma mactroides (Defeo et al. 1986) and Donax hanleyanus (Defeo \& de Alava 1995), the mole crab Emerita brasiliensis (Lercari \& Defeo 1999), and the ovoviviparous cirolanid isopod Excirolana armata (Lozoya \& Defeo 2006). This isopod is the most conspicuous intertidal species on the Atlantic sandy beaches of South America, and is particularly abundant on the $22 \mathrm{~km}$ of continuous sandy coast considered in this study (de Alava \& Defeo 1991). E. armata has been identified as a primary consumer (trophic level range 1.9 to 2.4) with scavenger habits. Together with its reduced mobility, this makes the species a suitable indicator of dominant sources of organic matter in beach ecosystems (Bergamino et al. 2011). However, the contribution of allochthonous organic matter from the Andreoni Canal has not been assessed. In the current study, we examined the utilization of organic sources derived from Andreoni Canal discharge by E. armata. To this end, we evaluated spatial variations in $\delta^{13} \mathrm{C}$ and $\delta^{15} \mathrm{~N}$, in $\mathrm{POM}$, in terrestrial organic matter (TOM) and in the sandybeach isopod itself, at various distances from the freshwater source.

\section{MATERIALS AND METHODS}

\section{Study site}

The study area comprises $22 \mathrm{~km}$ of uninterrupted exposed sandy beach situated between La Coronilla $\left(33^{\circ} 50^{\prime} \mathrm{S}, 53^{\circ} 27^{\prime} \mathrm{W}\right)$ to the south, and Barra del Chuy $\left(33^{\circ} 40^{\prime} \mathrm{S}, 53^{\circ} 20^{\prime} \mathrm{W}\right)$ to the north, along the Atlantic coast of Uruguay. This is a microtidal dissipative beach with fine to very fine well-sorted sands (mean grain size $=0.20 \mathrm{~mm})$, a gentle slope $(3.53 \%)$, heavy wave action, a wide surf zone and the highest macrofauna richness (from 21 to 29 species), abundance and biomass of all Uruguayan beaches (Lercari \& Defeo 2006). The southern boundary of this beach is the Andreoni Canal, a freshwater source that drains an area of $\sim 270000$ ha into the ocean. Its flow is variable, depending on rainfall and agricultural (i.e. rice farming) water usage upstream, but it has been measured as high as $89 \mathrm{~m}^{3} \mathrm{~s}^{-1}$, tending to be highest during winter rainfall events (UNESCO 1980). The predominant direction of discharge, to the $\mathrm{NE}$, generates a strong alongshore salinity gradient that affects the resident macrofauna along the beach (Lercari \& Defeo 1999, Sauco et al. 2010).

\section{Sample collection and stable isotope analysis}

Biological samples for stable isotope analysis were collected in December 2009 and February 2010 at 3 different sites: Barra del Chuy (hereinafter Barra), the least impacted site, at $13 \mathrm{~km}$ from the freshwater discharge; Coronilla, moderately impacted, at $1 \mathrm{~km}$ from the canal mouth; and Andreoni, the most highly impacted site, at the canal mouth (see Fig. 1 in Lercari et al. 2002). Long-term studies have shown that salinity markedly decreases from Barra (mean $\pm \mathrm{SE}$ : $25.4 \pm 1.3)$ to Coronilla $(21.32 \pm 1.6)$ and Andreoni $(5.7 \pm 1.4$; Lercari \& Defeo 2003 and references 
therein). We sampled twice and pooled data from each site to aid in the interpretation of the isotopic distribution and to capture the temporal fluctuation of basal resources (Post 2002, Hill et al. 2008).

For each time-and-site combination, 3 replicates of POM, TOM and isopods were collected. Seawater POM (phytoplankton and detritus) was obtained by filtering $5 \mathrm{l}$ of surface water through a $63 \mu \mathrm{m}$ mesh to remove zooplankton and coarse sediment particles that do not contribute to the diet of Excirolana armata (Bergamino et al. 2011). This filtrate was then filtered through a pre-combusted $\left(500^{\circ} \mathrm{C}\right.$ for $\left.4 \mathrm{~h}\right)$ Whatman $\mathrm{GF} / \mathrm{F}$ filter. TOM samples were obtained from detritus aggregation (dominated by terrestrial vascular plant debris) deposited on the beach face at the canal mouth only. No macrodetritus was found at Barra or Coronilla during either sampling event. Sediment organic matter was not assessed, since, due to the very low organic matter content of this beach, it would provide only a weak isotopic signal (Bergamino et al. 2011). For isopods, 3 independent sampling units spaced $8 \mathrm{~m}$ apart were taken with a $27 \mathrm{~cm}$ diameter cylinder and to a depth of $40 \mathrm{~cm}$ along the intertidal zone of each site and sieved through a $0.5 \mathrm{~mm}$ mesh. The isopods retained in each sampling unit were kept in filtered water overnight for gut clearance before being frozen at $-20^{\circ} \mathrm{C}$. For each replicate, some 10 to 15 isopods of similar size were selected for isotopic determination.

In order to carry out the isotope analysis, samples were rinsed with distilled water, dried at $50^{\circ} \mathrm{C}$ for $24 \mathrm{~h}$, ground with mortar and pestle, and finally placed into a $5 \times 8 \mathrm{~mm}$ tin capsule. In order to avoid alterations in isotopic measurements, samples were not acidified (Serrano et al. 2008).

Carbon and nitrogen isotope ratios were assessed at the University of California, Davis, USA, by continuous-flow isotope-ratio mass spectrometry (20-20 mass spectrometer, PDZ Europa) after sample combustion to $\mathrm{CO}_{2}$ and $\mathrm{N}_{2}$ at $1000^{\circ} \mathrm{C}$ in an on-line elemental analyser (ANCA-GSL, PDZ Europa). Nitrogen and $\mathrm{CO}_{2}$ were separated on a Carbosieve ${ }^{\mathrm{TM}} \mathrm{GC}$ column $\left(65^{\circ} \mathrm{C}, 65 \mathrm{ml} \mathrm{min}^{-1}\right)$ before input into the mass spectrometer.

Carbon and nitrogen isotopic composition $\left(\delta^{13} \mathrm{C}\right.$ and $\delta^{15} \mathrm{~N}$ ) were expressed as the relative difference between isotopic ratios in the sample and in conventional standards (Vienna Pee Dee Belemnite for carbon, and atmospheric $\mathrm{N}_{2}$ for nitrogen) using the standard equation:

$$
\delta^{13} \mathrm{C} \text { or } \delta^{15} \mathrm{~N}(\%)=\left[\left(\mathrm{R}_{\text {sample }} / \mathrm{R}_{\text {standard }}\right)-1\right] \times 1000
$$

where $\mathrm{R}$ is ${ }^{13} \mathrm{C} /{ }^{12} \mathrm{C}$ or ${ }^{15} \mathrm{~N} /{ }^{14} \mathrm{~N}$.

\section{Data analysis}

In order to quantify the feasible contribution of food sources to the diet of Excirolana armata at each site, we used the IsoSource software (Phillips \& Gregg 2003), which computes a range of probability contributions to consumers for each food source. Isotopic signature was adjusted in consideration of an isotopic fractionation (i.e. enrichment) of $0.4 \%$ for $\delta^{13} \mathrm{C}$ and $3.4 \%$ for $\delta^{15} \mathrm{~N}$ (Post 2002). We used tolerance parameters of 0.5 to $1.5 \%$. POM and TOM derived from the Andreoni Canal were considered as main food sources. Small ranges between minima and maxima represent well-constrained estimates of the different source contributions (Phillips \& Gregg 2003).

\section{RESULTS}

The isotopic composition of POM showed high variability between sites (Fig. 1). $\delta^{13} \mathrm{C}$ values for POM $($ mean $\pm \mathrm{SE})$ decreased from Barra $(-18.56 \pm 0.44)$, the most distant site from the freshwater discharge, to Coronilla (-20.32 \pm 0.74$)$ and Andreoni (-23.06 \pm 1.03). TOM collected in Andreoni exhibited the most depleted $\delta^{13} \mathrm{C}$ values $(-27.20 \pm 0.04$; Fig 1$)$. $\delta^{15} \mathrm{~N}$ values for POM decreased from Barra to Coronilla and Andreoni (Fig. 1).

Excirolana armata showed more depleted $\delta^{13} \mathrm{C}$ values at Andreoni $(-22.02 \pm 0.47)$ and Coronilla $(-21.70 \pm 0.36)$ than at Barra $(-17.03 \pm 0.06) . \delta^{15} \mathrm{~N}$

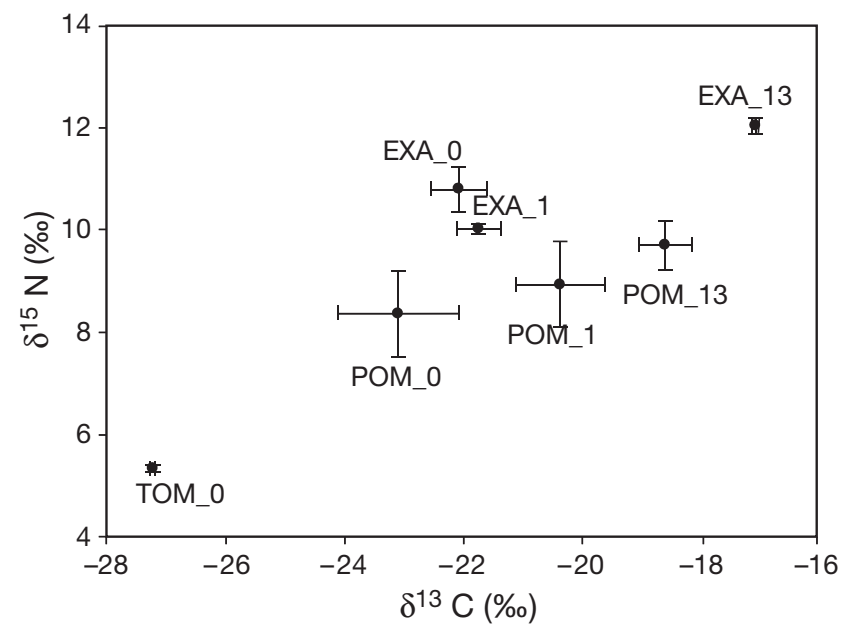

Fig. 1. $\delta^{13} \mathrm{C}$ and $\delta^{15} \mathrm{~N}$ values (mean $\pm \mathrm{SE}$ ) in particulate organic matter (POM), terrestrial organic matter (TOM) and in the sandy-beach isopod Excirolana armata (EXA) for each site. $0,1,13$ : distance in $\mathrm{km}$ of each sampling site from canal mouth 
Table 1. Excirolana armata. Feasible contributions (\%) of particulate organic matter (POM) and terrestrial organic matter (TOM) to diet of E. armata (EXA) at each sampling site, as determined by IsoSource modeling (Phillips \& Gregg 2003). Ranges shown are from 1st to 99th percentile; mean values in parentheses. $0,1,13$ : distance in $\mathrm{km}$ of each sampling site from canal mouth

\begin{tabular}{|lrlcrr|}
\hline & POM_13 & POM_1 & POM_0 & TOM_0 & N \\
\hline EXA_13 & 80-99 (92) & $0-19(6)$ & $0-7(2)$ & $0-3(0.8)$ & 224 \\
EXA_1 & $0-53(20)$ & $0-64(24)$ & $0-75(24)$ & $14-52(32)$ & 45748 \\
EXA_0 & $0-54(24)$ & $0-64(27)$ & $0-36(12)$ & $26-47(36)$ & 10073 \\
\hline
\end{tabular}

values of E. armata were higher at Barra (12.02 \pm 0.15) than at Coronilla (10.01 \pm 0.09$)$ and Andreoni $(10.78 \pm 0.46)$ (Fig. 1).

IsoSource estimates of potential contributions from TOM to isopod mixtures were very good, near the respective weighted means and within narrow ranges. With regard to potential POM contributions, estimated values were acceptable. Mixing-model outputs (Table 1) showed that, of the sources included in the mixing model at Barra, POM was the main contributor to the diet of E. armata. TOM, on the other hand, is what was mostly assimilated by isopods at Coronilla and Andreoni.

\section{DISCUSSION}

Using stable isotope analysis, this study showed a clear trophic subsidy from the canal discharge in the sandy beach isopod Excirolana armata. The pattern of variation in $\delta^{13} \mathrm{C}$ usually shows a decreasing trend from marine to terrestrial regions (Rubenstein \& Hobson 2004). Consistently, we found a decreasing trend in $\delta^{13} \mathrm{C}$ values in POM and in E. armata from the site least influenced by terrigenous materials (Barra) to the site closest to the canal mouth (Andreoni). This demonstrates the influence of the discharge, which contributes terrestrial material to the beach ecosystem that is assimilated by E. armata. At Coronilla, isotopic POM values were between those measured at Andreoni and Barra. This may be attributed to a marked dilution of fresh and marine waters at Coronilla, which generates a high variability in salinity at this site (Lercari \& Defeo 1999).

Results from mixing models suggest that isopods are supported by different food sources at each site. TOM contributed over $26 \%$ of the diet of Excirolana armata at Andreoni and Coronilla, demonstrating that terrestrial allochthonous inputs form an important food source of this organism at these sites. By contrast, among the food sources included in the mix- ing model, marine POM was the main contributor to the diet of $E$. armata at the site least influenced by canal discharge (Barra). We are aware that differences between TOM and isopod signatures indicate at least 3 to 5 trophic levels between the carbon source and the animals. However, previous studies using stable isotopes have reported close trophic relationships between sandy-beach invertebrates and terrestrial subsidies (Paetzold et al. 2008, Colombini et al. 2011). Moreover, intertidal isopods, by scraping the sediment surface, consume a wide variety of resources ranging from macroalgae to animal matter and detritus (Arrontes 1990, McLachlan \& Brown 2006, Schlacher et al. 2008); they also show the ability to hydrolytically digest cellulose and oxidatively break down lignins, both of which are common components of leaf litter (Zimmer at al. $2001,2002)$. Therefore, it is suggested that, due to the enriched isotopic signatures of E. armata, other components not detected during our sampling (e.g. carrion, animal carcasses), might contribute to its diet. The low $\delta^{13} \mathrm{C}$ values of TOM are in agreement with terrestrial C3 plant values, which range from -30 to $-23 \%$ (Fry \& Sherr 1984, Peterson \& Fry 1987). We have also shown that TOM was consumed by the isopod at Coronilla, closer to the canal discharge, even though the sporadic input usually observed at this site precluded the detection of this food source during sampling. This is in agreement with previous findings on small-plume discharges, which have highlighted the fact that brief allochthonous inputs to nearshore marine waters have a limited zone of influence (Gaston et al. 2006, Connolly et al. 2009). It should be noted that TOM could also be indirectly assimilated by E. armata via POM, since fragmentation and physical transport of TOM can account for a large proportion of the organic component of seawater POM (Polis et al. 1997). The action of physical processes (e.g. storms, swash dynamics), together with large inputs of TOM from the canal discharge into the beach environment, could lead to TOM being incorporated into the marine ecosystem (e.g. McLeod \& Wing 2009).

Several studies have mentioned the use of $\delta^{15} \mathrm{~N}$ as an indicator of anthropogenic nitrogen inputs (e.g. Anderson \& Cabana 2006). Human wastewater and livestock waste nitrogen are enriched in $\delta^{15} \mathrm{~N}$ (from 10 to $20 \%$ o), while synthetic fertilizers and atmospheric nitrogen typically have low $\delta^{15} \mathrm{~N}$ values (atmospheric, from 2 to $8 \%$; inorganic fertilizer, from -3 to $3 \%$; Valiela et al. 2000). Our results showed a decreasing trend in $\delta^{15} \mathrm{~N}$ values, both for POM and isopods, towards the site nearest to the discharge 
(Andreoni). This suggests the upstream use of synthetic fertilizers, which are in fact usually employed in the rice fields adjacent to the Andreoni Canal (Irisarri et al. 2007), and which likely contribute to the soil N pool of the system (Kundu \& Ladha 1995). Moreover, the high variability in $\delta^{15} \mathrm{~N}$ in isopods at Andreoni may indicate a higher degree of omnivory or diet variation at this site affected most directly by the freshwater discharge. This fact opens a new question regarding the consequences of trophic subsidy for adaptive trophic behaviour, and the dynamics of the sandy-beach food web.

In summary, our study reinforces the notion that terrestrial runoff and small plumes constitute important linkages between marine and terrestrial ecosystems (Darnaude et al. 2004, Connolly et al. 2009), but that their zone of influence may be limited (Gaston et al. 2006). This link increases food sources in marine ecosystems, but may also lead to transport of contaminated sediments to sea, even forming a contaminant 'imprint' on the seafloor (Dagg et al. 2004, Gaston et al. 2006). Similar isotopic depletion in coastal benthic invertebrates has been recognized as caused by the assimilation of TOM originating from freshwater discharges (Riera \& Richard 1997, Darnaude at al. 2004, Schlacher \& Connolly 2009). Particularly for sandybeach ecosystems, we have demonstrated the important role played by TOM coming from a freshwater discharge in the food diet of the most conspicuous inhabitant of SW Atlantic sandy shores, viz. Excirolana armata. Therefore, cirolanid isopods, which have been recognized as reliable monitoring species of human impacts on sandy beaches (Veloso et al. 2011), may also be used to trace the fate of TOM on these beaches.

Acknowledgements. We are grateful to the Benthic Ecology Group of Uruguay's Unidad de Ciencias del Mar for field and laboratory assistance. Support from projects ANII-FCE2007 (Project No. 274) and DINARA/FAO/GEF (ID 3410) is also acknowledged. We thank 4 anonymous reviewers for useful comments that substantially improved this article.

\section{LITERATURE CITED}

> Anderson C, Cabana G (2006) Does $\delta^{15} \mathrm{~N}$ in river food webs reflect the intensity and origin of $\mathrm{N}$ loads from the watershed? Sci Total Environ 367:968-978

Arrontes J (1990) Diet, food preference and digestive efficiency in intertidal isopods inhabiting macroalgae. J Exp Mar Biol Ecol 139:231-249

> Bergamino L, Lercari D, Defeo O (2011) Food web structure of sandy beaches: temporal and spatial variation using stable isotope analysis. Estuar Coast Shelf Sci 91:536-543 Colombini I, Brilli M, Fallaci M, Gagnarli E, Chelazzi L
(2011) Food webs of a sandy beach macroinvertebrate community using stable isotopes analysis. Acta Oecol 37 : 422-432

> Connolly RM, Schlacher TA, Gaston TF (2009) Stable isotope evidence for trophic subsidy of coastal benthic fisheries by river discharge plumes off small estuaries. Mar Biol Res 5:164-171

- Dagg MJ, Benner R, Lohrenz S, Lawrence D (2004) Transformation of dissolved and particulate materials on continental shelves influenced by large rivers: plume processes. Cont Shelf Res 24:833-858

> Darnaude AM, Salen-Picard C, Harmelin-Vivien ML (2004) Depth variation in terrestrial particulate organic matter exploitation by marine coastal benthic communities off the Rhone River delta (NW Mediterranean). Mar Ecol Prog Ser 275:47-57

de Alava A, Defeo O (1991) Distributional pattern and population dynamics of Excirolana armata (Isopoda: Cirolanidae) in a Uruguayan sandy beach. Estuar Coast Shelf Sci 33:433-444

Defeo O, de Alava A (1995) Effects of human activities on long-term trends in sandy beach populations: the wedge clam Donax hanleyanus in Uruguay. Mar Ecol Prog Ser 123:73-82

Defeo O, Layerle C, Masello A (1986) Spatial and temporal structure of the yellow clam Mesodesma mactroides (Deshayes, 1854) in Uruguay. Medio Ambiente (Chile) 8:48-57

$>$ Defeo O, McLachlan A, Schoeman DS, Schlacher T and others (2009) Threats to sandy beach ecosystems: a review. Estuar Coast Shelf Sci 81:1-12

Fry B (2006) Stable isotope ecology. Springer, New York, NY

Fry B, Sherr EB (1984) $\delta^{13} \mathrm{C}$ measurements as indicators of carbon flow in marine and freshwater ecosystems. Contrib Mar Sci 27:13-47

> Gaston TF, Schlacher TA, Connolly RM (2006) Flood discharges of a small river into open coastal waters: plume traits and material fate. Estuar Coast Shelf Sci 69:4-9

> Hill JM, McQuaid CD, Kaehler S (2008) Temporal and spatial variability in stable isotope ratios of SPM link to local hydrography and longer term SPM averages suggest heavy dependence of mussels on nearshore production. Mar Biol 154:899-909

> Irisarri P, Gonnet S, Monza J (2007) Cyanobacterial inoculation and nitrogen fertilization in rice. World J Microbiol Biotechnol 23:237-242

Kundu DK, Ladha JK (1995) Efficient management of soil and biologically fixed $\mathrm{N}_{2}$ in intensively cultivated rice fields. Soil Biol Biochem 27:431-439

Lercari D, Defeo O (1999) Effects of freshwater discharge in sandy beach populations: the mole crab Emerita brasiliensis in Uruguay. Estuar Coast Shelf Sci 49:457-468

> Lercari D, Defeo O (2003) Variation of a sandy beach macrobenthic community along a human-induced environmental gradient. Estuar Coast Shelf Sci 58:17-24

> Lercari D, Defeo O (2006) Large-scale diversity and abundance trends in sandy beach macrofauna along full gradients of salinity and morphodynamics. Estuar Coast Shelf Sci 68:27-35

Lercari D, Defeo O, Celentano E (2002) Consequences of a freshwater canal discharge on the benthic community and its habitat on an exposed sandy beach. Mar Pollut Bull 44:1397-1404

> Lozoya JP, Defeo O (2006) Effects of a freshwater canal discharge on an ovoviviparous isopod inhabiting an exposed sandy beach. Mar Freshw Res 57:421-428 
McLachlan A, Brown AC (2006) The ecology of sandy shores. Elsevier, Burlington, MA

McLeod RJ, Wing SR (2009) Strong pathways for incorporation of terrestrially derived organic matter into benthic communities. Estuar Coast Shelf Sci 82:645-653

Nakano S, Murakami M (2001) Reciprocal subsidies: dynamic interdependence between terrestrial and aquatic food webs. Proc Natl Acad Sci USA 98:166-170

Paetzold A, Lee M, Post DM (2008) Marine resource flows to terrestrial arthropod predators on a temperate island: the role of subsidies between systems of similar productivity. Oecologia 157:653-659

Peterson BJ, Fry B (1987) Stable isotopes in ecosystem studies. Annu Rev Ecol Syst 18:293-320

> Phillips DL, Gregg JW (2003) Source partitioning using stable isotopes: coping with too many sources. Oecologia 136:261-269

Polis GA, Anderson WB, Holt R (1997) Toward an integration of landscape and food web ecology: the dynamics of spatially subsidized food webs. Annu Rev Ecol Syst 28: 289-316

> Post DM (2002) Using stable isotopes to estimate trophic position: models, methods, and assumptions. Ecology 83: 703-718

Riera P, Richard P (1997) Temporal variation of $\delta^{13} \mathrm{C}$ in particulate organic matter and oyster Crassostrea gigas in Marennes-Oléron Bay (France): effect of freshwater inflow. Mar Ecol Prog Ser 147:105-115

Rubenstein DR, Hobson KA (2004) From birds to butterflies: animal movement patterns and stable isotopes. Trends Ecol Evol 19:256-263

Sampaio L, Rodrigues AM, Quintino V (2010) Carbon and nitrogen stable isotopes in coastal benthic populations under multiple organic enrichment sources. Mar Pollut Bull 60:1790-1802

Sauco S, Eguren G, Heinzen H, Defeo O (2010) Effects of herbicides and freshwater discharge on water chemistry, toxicity and benthos in a Uruguayan sandy beach. Mar Environ Res 70:300-307

Editorial responsibility: Hans Heinrich Janssen, Oldendorf/Luhe, Germany
Schlacher TA, Connolly RM (2009) Land-ocean coupling of carbon and nitrogen fluxes on sandy beaches. Ecosystems (NY) 12:311-321

Schlacher TA, Dugan J, Schoeman DS, Lastra M and others (2007) Sandy beaches at the brink. Divers Distrib 13: 556-560

Schlacher TA, Schoeman DS, Dugan J, Lastra M, Jones A, Scapini F, McLachlan A (2008) Sandy beach ecosystems: key features, sampling issues, management challenges and climate change impacts. Mar Ecol 29:70-90

Serrano O, Serrano L, Mateo MA, Colombini I, Chelazzi L, Gagnarli E, Fallaci M (2008) Acid washing effect on elemental and isotopic composition of whole beach arthropods: implications for food web studies using stable isotopes. Acta Oecol 34:89-96

UNESCO (United Nations Educational, Scientific and Cultural Organization) (1980) Proyecto de Conservación y mejora de playas, UNDP/URU/73/007. Ministerio de Transporte y Obras Públicas, Montevideo

> Valiela I, Geist M, McClelland J, Tomasky G (2000) Nitrogen loading from watersheds to estuaries: verification of the Waquoit Bay nitrogen loading model. Biogeochemistry 49:277-293

> Veloso GV, Neves G, de Almeida Capper L (2011) Sensitivity of a cirolanid isopod to human pressure. Ecol Indic 11:782-788

- Vizzini S, Mazzola A (2006) The effects of anthropogenic organic matter inputs on stable carbon and nitrogen isotopes in organisms from different trophic levels in a southern Mediterranean coastal area. Sci Total Environ 368:723-731

Zimmer M, Danko JP, Pennings SC, Danford AR, Ziegler A, Uglow RF, Carefoot TH (2001) Hepatopancreatic endosymbionts in coastal isopods (Crustacea: Isopoda), and their contribution to digestion. Mar Biol 138:955-963

Zimmer M, Danko JP, Pennings AR, Danford AR, Carefoot TH, Ziegler A, Uglow RF (2002) Cellulose digestion and phenol oxidation in coastal isopods (Crustacea: Isopoda). Mar Biol 140:1207-1213

Submitted: April 18, 2011; Accepted: November 7, 2011 Proofs received from author(s): December 28, 2011 